\title{
WIND ENERGY DEVELOPMENT IN JAPAN AND VIETNAM
}

\author{
Phan Anh Tuan \\ Department of Ship Engineering and Fluid Mechanics, School of Transportation Engineering, Hanoi \\ University of Science and Technology, Hanoi, Vietnam, Tel: +84 988783978, \\ e-mail: tuan.phananh@hust.edu.vn
}

Received Date: October 25, 2017; Revised Date: December 18, 2018; Acceptance Date: December 25, 2018

\begin{abstract}
This paper represents a research study on the wind power policies and the development of wind power projects in Japan and Vietnam, two countries in Asia with different social development history and economy. Japan has harnessed wind power as a source of green energy many years ago whereas the research on wind power in Vietnam has only been conducted in recent decades. After the earthquake-tsunami disaster in 2011, the Japanese government has prioritized the development of alternative sources of generating electricity including wind power to replace the dangerous nuclear power. This paper reviews and analyzes the development of wind power policies and projects both in Japan and Vietnam. The research results confirm that the Japanese government has the complete and clear policies on the development of wind power. This stability encourages national and foreign investment in the various development projects of the wind power plants. On the other hand, the laws and policies for wind development in Vietnam are not yet stable and many Decisions and Circulars have been promulgated over a decade by the Vietnamese government from 2007 to 2016 which result in the constraint of the development of wind power projects in Vietnam.
\end{abstract}

Keywords: Circular, Decision, Green energy, Japan, Policy, Vietnam, Wind power

\section{Introduction}

The result of the Fukushima accident in 2011 and subsequent shut-downs of reactors elsewhere signaled that the nuclear power production in Japan will not be on the same level as the pre-Fukushima period. To offset the shortfall, oil and gas have generated nearly 90 percent of the nation's electricity, with hydropower accounting for about 8 percent and other renewables - solar, wind, geothermal and biogas - making up the balance.

The wind power generation in Japan started in 1980, but began in full-force with the introduction of 1,000 kW generating systems in 1999. Many wind turbines have been installed in Hokkaido, Tohoku and Kyushu where the wind conditions are desirable. The government has been supporting the wind energy development since early 1990s. Many research projects and field-tests have been financed by the government and conducted mostly by New Energy and Industrial Technology Development Organization (NEDO). Laws and regulations have been reviewed and subsidies for constructions were handed-out until 2010. Those supply-side support schemes were to be terminated before the Fukushima accident in 2011.

According to World Bank, the potential for wind energy development in Vietnam is considerably higher when compared to Thailand, Laos or Cambodia [1]. A World Bank survey estimated the total potential of wind power at 513,360 MW equivalent to 200 times the output of Southeast Asia's largest power plant, the Son La Hydroelectric Plant in 
northern Vietnam and ten times the entire national capacity forecast for 2020. Starting in the 1980s, the Institute of Energy (IE) has been commissioned by the Ministry of Electricity (now Ministry of Industry and Trade) to review the erection of wind turbines on islands and in remote grid connected areas in Vietnam. Observations and calculations showed that around 28,000 square kilometer of Vietnam have average wind speeds of 7 $\mathrm{m} / \mathrm{s}$ to $9 \mathrm{~m} / \mathrm{s}$ at a height of 65 meters.

The Ministry of Trade and Industry is developing a Strategy and Master plan for Renewable Energy Development of Vietnam for the period up to the year 2015, with an outlook to 2025. Under this plan, the renewable energy will increase to $5 \%$ of the total national energy output, with wind and solar power accounting for half of the amount.

Currently, all important wind energy projects are supported by the State Bank of Vietnam but financial support may also be possible from the World Bank and the Asian Development Bank. There are not many wind energy projects in Vietnam at present due to the lack of stable policies and processes in place.

This paper discusses the potential of wind energy aspect as well as the policies for the development of wind projects in Japan and Vietnam. This study will give Vietnam insights to learn invaluable lessons from the policies and development of wind energy projects in Japan.

\section{Wind Potential}

\section{Wind Potential in Japan}

Wind resource is quite abundant in Japan [2]. Table 1 shows the potential wind resource in Japan both onshore and offshore. There are three main abundant wind resource locations. They are Hokkaido, Tohoku and Kyushu islands.

Table 1. Potential of Wind Energy in Japan

\begin{tabular}{cccc} 
Location & Hokkaido & Tohoku & Kyushu \\
\hline Onshore & $139.6 \mathrm{GW}$ & $72.6 \mathrm{GW}$ & $20.9 \mathrm{GW}$ \\
Offshore & $403 \mathrm{GW}$ & $224.8 \mathrm{GW}$ & $454.6 \mathrm{GW}$ \\
\hline
\end{tabular}

Figure 1 shows the onshore wind resource of Japan. This figure shows that the highest wind power is Hokkaido area and the lowest wind power is in Kyushu. The estimation of the total potential wind power onshore in Japan is about $282.9 \mathrm{GW}$. The common range wind speed onshore in Japan is from $5.5 \mathrm{~m} / \mathrm{s}$ to $8.5 \mathrm{~m} / \mathrm{s}$.

Figure 2 shows the offshore wind resource of Japan. This figure shows that the offshore wind power is more abundant if compared to the onshore wind resource. The total potential of wind power offshore is $1572.6 \mathrm{GW}$. There is no similarity between onshore and offshore wind resource characteristics in these locations in Japan. The onshore wind power in Hokkaido is the highest and the wind power in Kyushu is the lowest. The offshore wind power in Kyushu is the highest and the wind power in Tohoku is lowest. The average wind speed in offshore in Japan is from $6.5 \mathrm{~m} / \mathrm{s}$ to $8.5 \mathrm{~m} / \mathrm{s}$. In some locations, the wind speed reaches to more than $8.5 \mathrm{~m} / \mathrm{s}$. 


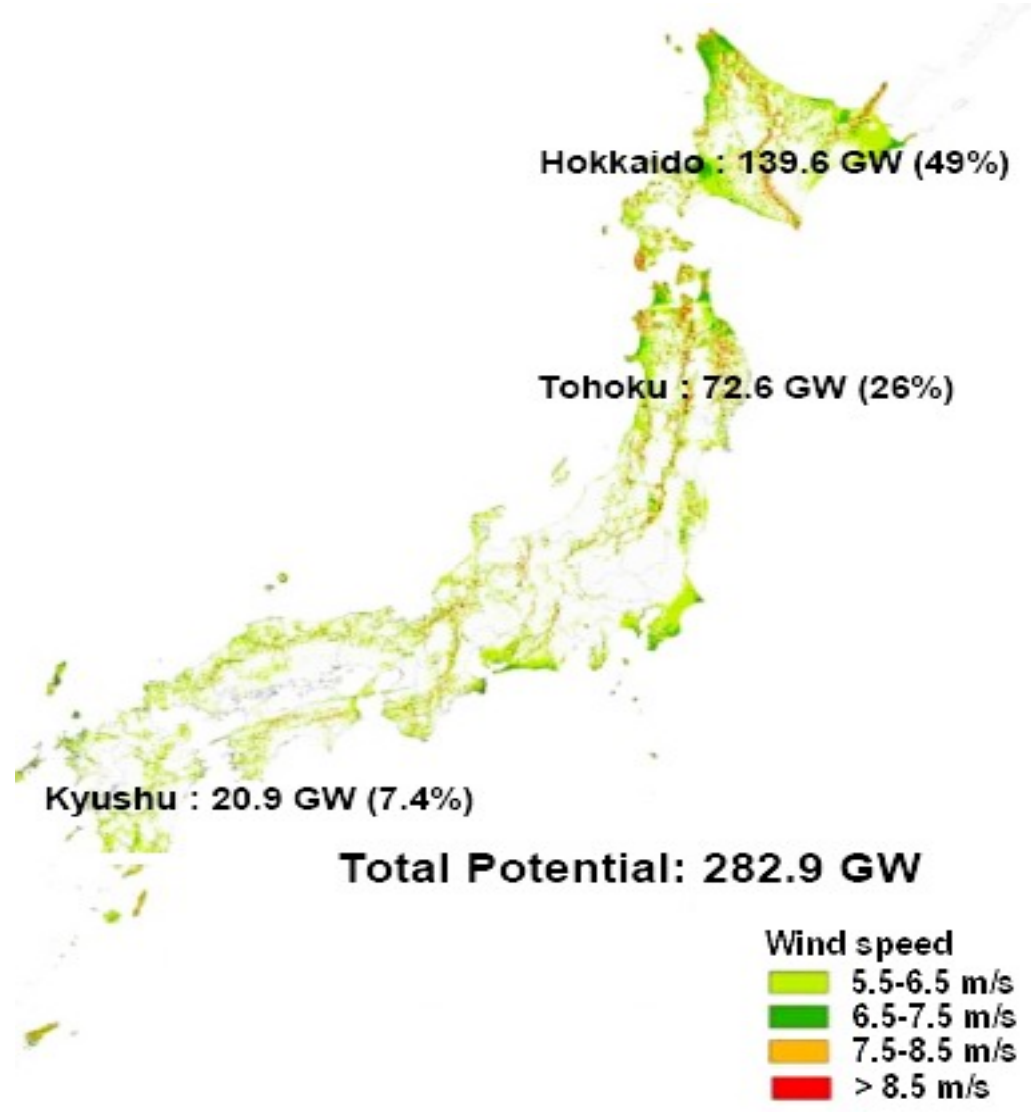

Figure 1. Onshore wind resource of Japan

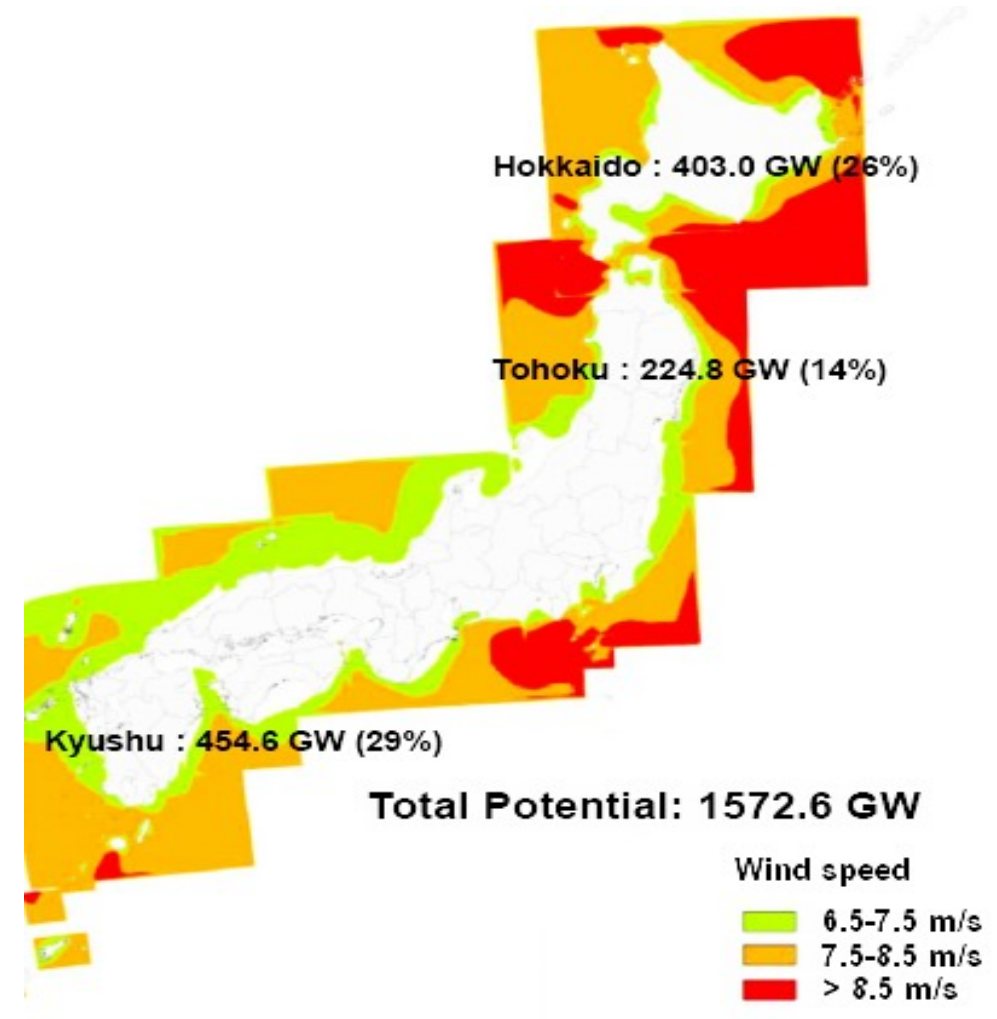

Figure 2. Offshore wind resource of Japan 


\section{Wind Potential in Vietnam}

With a coastline of 3,000 km, and average wind speeds of $5.6 \mathrm{~m} / \mathrm{s}$ in coastal regions, and up to $8 \mathrm{~m} / \mathrm{s}$ on certain islands, the potential for wind power generation is high. The theoretical wind energy capacity in Vietnam is approximately 513 GW.

In 2007, the Electricity of Vietnam Group (EVN) evaluated the potential of wind energy in Vietnam and looked for locations to establish 1,785 MW electric wind energy generations [3]. According to EVN's study, the Central Vietnam has the highest potential of wind energy in the country. In which, Quangbinh and Binhdinh are the two provinces with highest potential for wind energy. There is a little difference in the result of the two studies of World Bank and EVN. Table 2 shows the result of World Bank and EVN studies on potential of wind energy at the height of $65 \mathrm{~m}$ from land surface in Vietnam.

In 2010, Vietnam Ministry of Industry and Trade (MoIT) and World Bank also had a co-study on building up a wind resource atlas for Vietnam. According to the study, the potential of wind energy in Vietnam at the height of $80 \mathrm{~m}$ from the land surface is $2,400 \mathrm{MW}$ and the mean wind speed is $7 \mathrm{~m} / \mathrm{s}$. Table 3 and Table 4 show the potential of wind energy in Vietnam at the height of $65 \mathrm{~m}$ and $80 \mathrm{~m}$ from the land surface [4].

Figure 3 shows the onshore wind resource of Vietnam. This wind resource atlas shows that the highest wind resource in Vietnam are located along beach. This figure also shows that wind speeds in the South and Middle of Vietnam are higher than the wind speed in the North of Vietnam.

Besides the onshore wind energy, the potential for offshore wind energy in Vietnam is also higher than the potential for offshore wind energy in other countries in ASEAN. It is estimated that the total wind energy in the southern middle coast and in southern Vietnam is around 5,000 billion $\mathrm{kWh}$ per year. This power is capable of supporting not only Vietnam's need for electricity but also its neighboring countries. Figure 4 shows the potential of wind energy on the offshore of Vietnam. This potential is estimated for wind resource at the height of $80 \mathrm{~m}$ from sea surface.

Table 2. Potential of Wind Energy at $65 \mathrm{~m}$ Height in Location

\begin{tabular}{clcc} 
No & \multicolumn{1}{c}{ Districts, Provinces } & \multicolumn{2}{c}{ Mean Wind Speed (m/s) } \\
& & EVN & WB \\
\hline 1 & Mongcai, Quangninh & 5.80 & 7.35 \\
2 & Vanly, Namdinh & 6.88 & 6.39 \\
3 & Samson, Thanhhoa & 5.82 & 6.61 \\
4 & Kyanh, Hatinh & 6.48 & 7.02 \\
5 & Quangninh, Quangbinh & 6.73 & 7.03 \\
6 & Giolinh, Quangtri & 6.53 & 6.52 \\
7 & Phuongmai, Binhdinh & 7.30 & 6.56 \\
8 & Tubang, Khanhhoa & 5.14 & 6.81 \\
9 & Phuocminh, Binhthuan & 7.22 & 8.03 \\
10 & Dalat, Lamdong & 6.88 & 7.57 \\
11 & Tuyphong, Binhthuan & 6.89 & 7.79 \\
12 & Duyenhai, Travinh & 6.47 & 7.24 \\
\hline
\end{tabular}


Table 3. Potential of Wind Energy at 65m Height

\begin{tabular}{|c|c|c|c|c|c|}
\hline Wind Speed & $<6 \mathrm{~m} / \mathrm{s}$ & $6-7 \mathrm{~m} / \mathrm{s}$ & $7-8 \mathrm{~m} / \mathrm{s}$ & $8-9 \mathrm{~m} / \mathrm{s}$ & $>9 \mathrm{~m} / \mathrm{s}$ \\
\hline Area $\left(\mathrm{km}^{2}\right)$ & 197,242 & 100,367 & 25,679 & 2,178 & 111 \\
\hline Area (\%) & 60.60 & 30.80 & 7.90 & 0.70 & 0 \\
\hline Power (MW) & NA & 401,444 & 102,716 & 88,748 & 452 \\
\hline
\end{tabular}

Table 4. Potential of Wind Energy at $80 \mathrm{~m}$ Height

\begin{tabular}{cccccccc}
$\begin{array}{c}\text { Wind } \\
\text { Speed }\end{array}$ & $\begin{array}{c}<\mathbf{4} \\
\mathbf{m} / \mathbf{s}\end{array}$ & $\begin{array}{c}\mathbf{4 - 5} \\
\mathbf{m} / \mathbf{s}\end{array}$ & $\begin{array}{c}\mathbf{5 - 6} \\
\mathbf{m} / \mathbf{s}\end{array}$ & $\begin{array}{c}\mathbf{6 - 7} \\
\mathbf{m} / \mathbf{s}\end{array}$ & $\begin{array}{c}\mathbf{7 - 8} \\
\mathbf{m} / \mathbf{s}\end{array}$ & $\begin{array}{c}\mathbf{8 - 9} \\
\mathbf{m} / \mathbf{s}\end{array}$ & $\begin{array}{c}>\mathbf{9} \\
\mathbf{m} / \mathbf{s}\end{array}$ \\
\hline $\begin{array}{c}\text { Area } \\
\left(\mathrm{km}^{2}\right)\end{array}$ & 95,916 & 70,868 & 40,473 & 2,435 & 222 & 20 & 1 \\
Area (\%) & 45.7 & 33.8 & 19.3 & 1.2 & 0.1 & 0.01 & 0 \\
$\begin{array}{c}\text { Power } \\
\text { (MW) }\end{array}$ & 956,11 & 708,678 & 404,732 & 24,351 & 2,202 & 200 & 10 \\
\hline
\end{tabular}

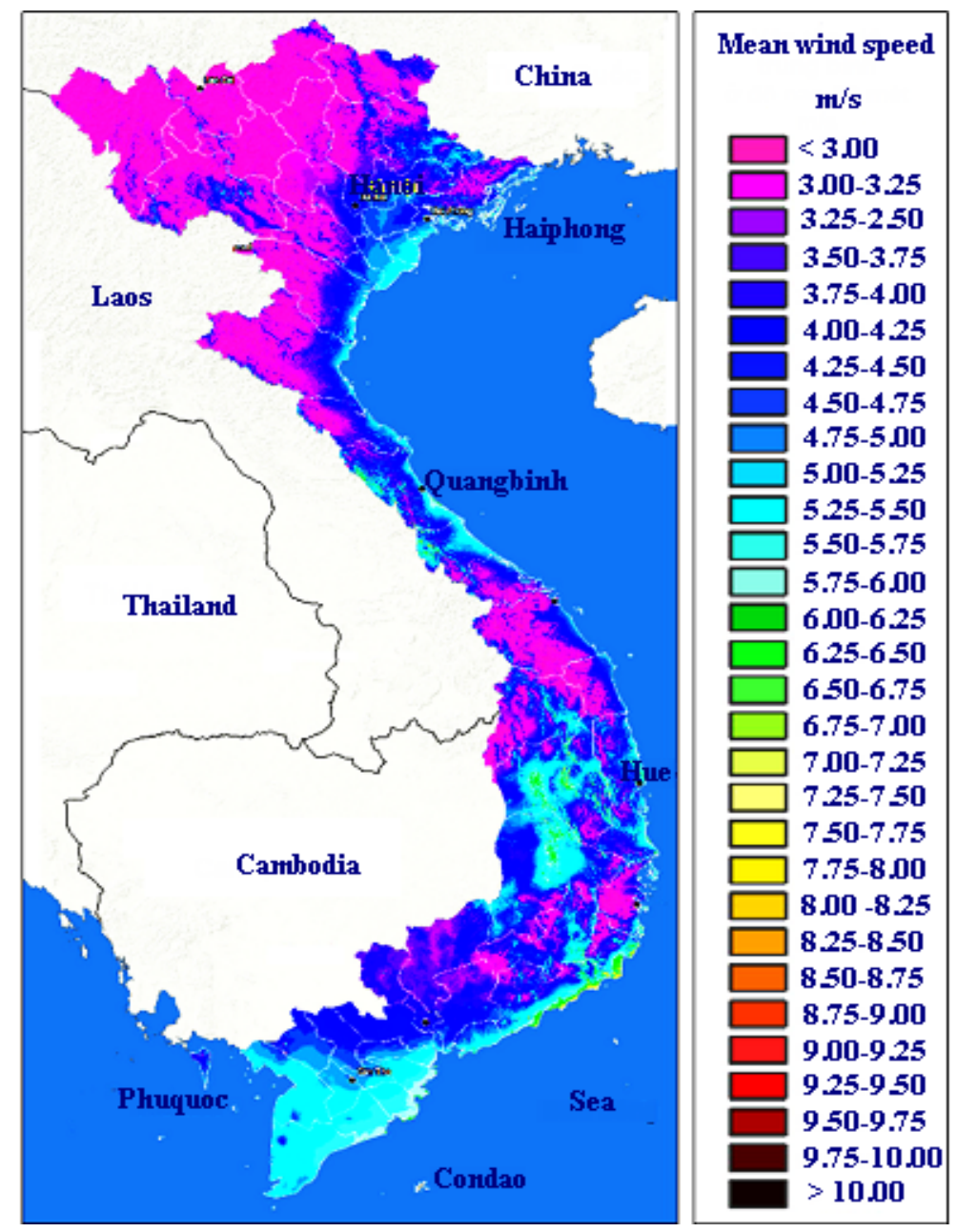

Figure 3. Onshore wind resource of Vietnam 
Figure 4 shows that the ideal location for the installation of wind turbines in the offshore of Vietnam is the south middle offshore. In this offshore area, the mean wind speed is around $10 \mathrm{~m} / \mathrm{s}$.

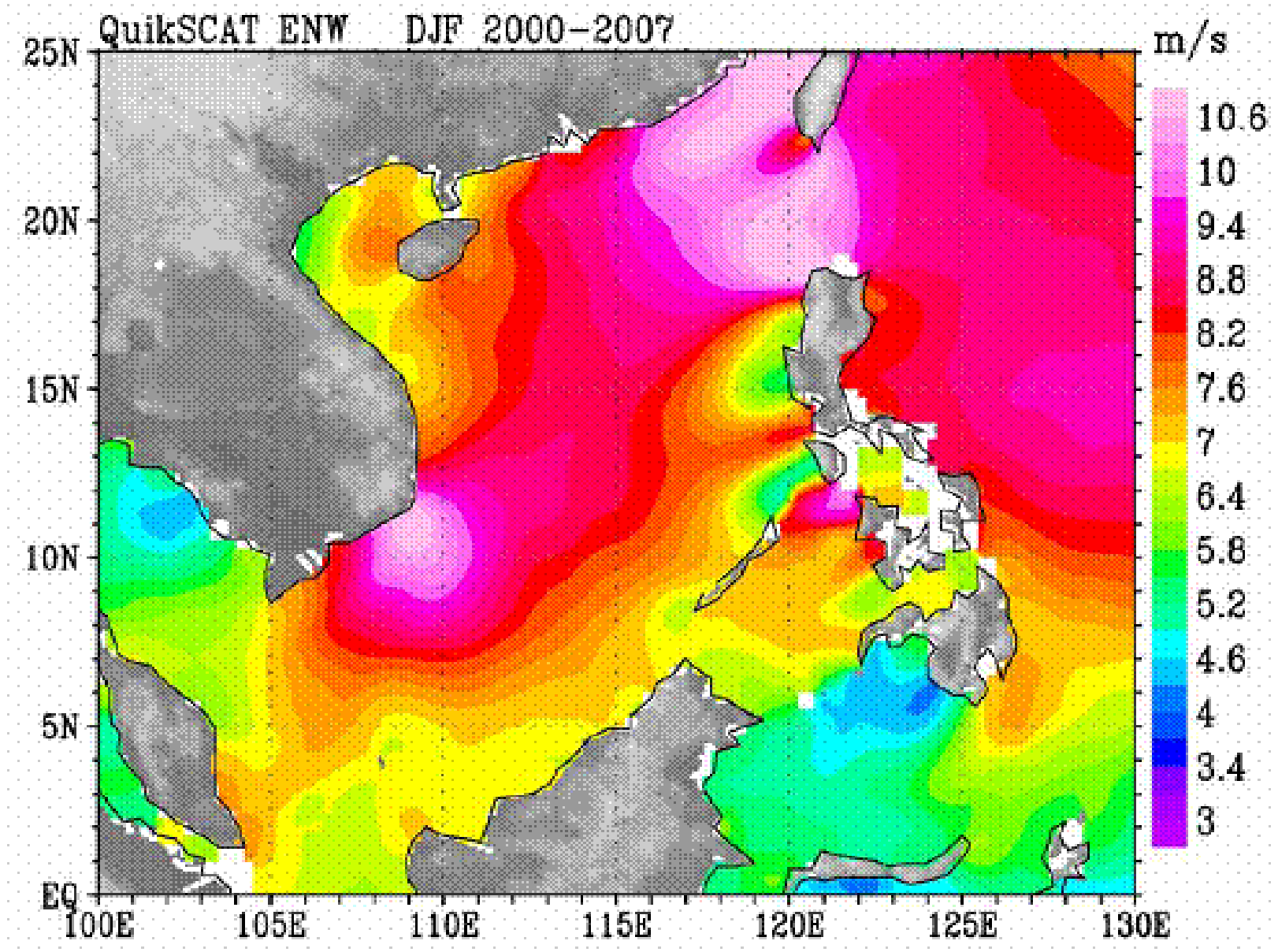

Figure 4. Offshore wind resource of Vietnam

\section{Wind Energy Policies and Projects}

\section{Wind Policies and Projects in Japan}

In 1995, the Japanese government and the New Energy and Industrial Technology Development Organization (NEDO) started a promotional policy with subsidy-programs. In June 1997, the Law on Special Measures for Promotion of Utilization of New Energy (New Energy Law) was enacted, which encouraged wind-generation businesses in Japan. As a result, some large-scale commercial wind farms ranging from $20 \mathrm{MW}$ to $30 \mathrm{MW}$ were developed, and a rapid increase in wind-power capacity in Japan was recorded in the following three years.

At the United Nations (UN) Climate Change Conference in Kyoto in December 1997, the Japanese government agreed to reduce the output of greenhouse gases by $6 \%$ by 2010, compared to the 1990 level. To attain this target, the government has changed the target of wind power for 2010 from $300 \mathrm{MW}$ to 3,000 MW (ten times higher as planned) in the latest Primary Energy Supply Plan. The government will also support Japanese companies to get involved in offshore wind projects abroad. 
In 2003, Japan introduced a Renewable Energy Portfolio Standard (RPS), which was later replaced by a feed-in-tariff scheme to incentivize private investment in the renewables sector by offering highly competitive fixed long-term rates. The RPS required electric power companies to source a specific proportion of their electricity from renewable sources without fixed prices. As a cause of taking advantages in wind power development projects in the police, at the end of 2003, the total wind-power capacity in Japan was 506 MW, which corresponds to one-sixth of the national target for wind-power capacity by 2010.

Following the policies in that period, many wind turbines have been built in Japan. Among them were three big offshore wind turbine projects. The first one was built in Setana town, Hokkaido in 2004 with the power of $1.2 \mathrm{MW}(0.2 \mathrm{MW}$ x 6 turbines). The second one was built in Sakata city, Yamagata in 2004 with the power of 10 MW (2 MW x 5 turbines) and the third one was built in Kamisu City, Ibaraki in 2010 with the power of 14 MW (2 MW x 7 turbines) [5].

After the double funk disasters, earthquake and tsunami in Fukushima in 2011, the Japanese government has developed many wind projects, especially in offshore wind projects. That includes a project in Kashima port, Ibaraki by a private company (Wind Power Ibaraki, Inc.). The project operates on seven $2 \mathrm{MW}$ nearshore wind turbines from June 2010 and added one more turbine with the same output two years later. An offshore wind farm of around $100 \mathrm{MW}$ (5 MWx20 turbines) is under construction. In this project, the Japanese energy company Orix Corp has taken a 33.3\% stake [6]. The other wind project in Japan is the Fukushima wind project. The Ministry of Economy, Trade and Industry (METI) in Japan supported this offshore wind project that was initiated by a consortium including Japanese trading house Marubeni, Mitsubishi Heavy Industry (MHI), Mitsubishi Corp., IHI Marine United, Mitsui Engineering \& Shipbuilding, Nippon Steel, Hitachi, Furukawa Electric and Shimizu. The University of Tokyo and Mizuho Information \& Research Institute are also involved. The Fukushima Wind Project, is located about 12 miles off the coast of Fukushima, made way for the installation of a 2 MW wind turbine in November 2013. The turbine, which has a tower 220 meters above the sea, transmits electricity to the grid via submarine cable. A $5 \mathrm{MW}$ wind turbine is under construction. A $7 \mathrm{MW}$ wind turbine is also in plan for construction in this project. The government has allocated 50 billion yen ( $\$ 405$ million) for the project, which allows turbines to float in areas that are too deep for traditional towers fixed to the seafloor [7]. Besides these projects, many other wind power projects have been completed and some are still underway [8].

Compared with developed countries in the world, the policy for incentivizing in developing wind power in Japan is higher. With regards to wind power, onshore wind in Japan is benefiting from a generous feed-in-tariff compared to other countries like the U.K., China and Germany. For instance, onshore wind power installations $>20 \mathrm{~kW}$ benefit from a purchase price of $\$ 0.23 / \mathrm{kWh}$ for 20 years, compared to $\$ 0.11 / \mathrm{kWh}$ for 5 years in Germany [9], [10]. The Feed-in-tariff is shown in Table 5.

With this in mind, the wind power capacity in Japan is expected to reach 7.6 GW in 2016. However, the tariff is considered far too low to incentivize offshore wind power. Up until the first quarter of 2014, both onshore and offshore wind had the same purchase price at $\$ 0.23 / \mathrm{kWh}$. In April 2014, METI announced a new feed-in tariff to account for the higher costs of offshore wind technology, increasing the tariff by over $50 \%$ to $\$ 0.36 / \mathrm{kWh}$. Despite this increase to a subsidy that far exceeds others around the world, it is unclear whether this will provide sufficient returns for investors, with some developers claiming 
that $\$ 0.40 / \mathrm{kWh}$ will be necessary to kick-start the industry in Japan, due to higher base costs and a lack of suitable infrastructure and offshore experience in Japan.

Table 5. The Feed-in-Tariff for Wind Development in Japan

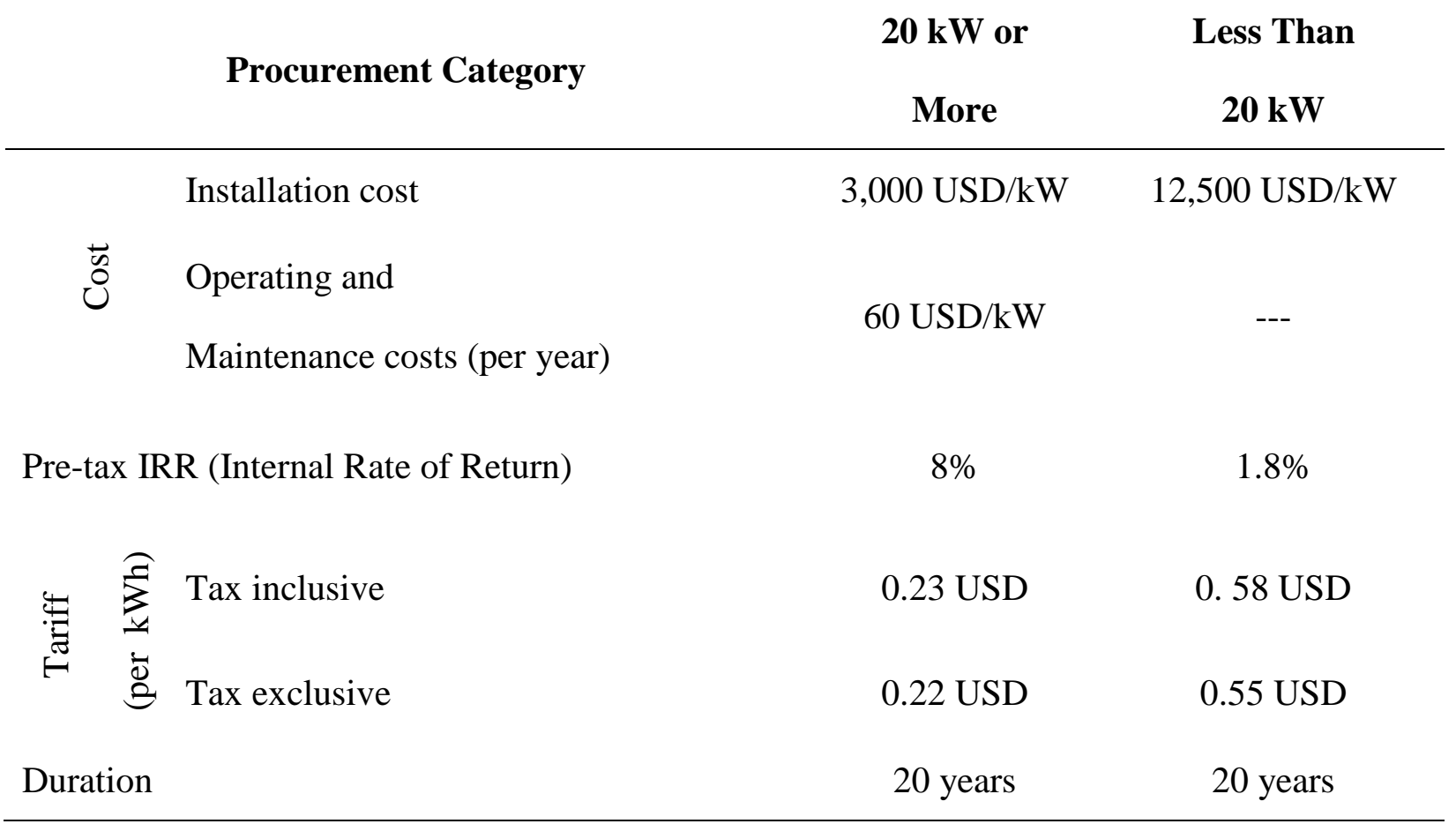

The Ministry of Economy, Trade and Industry, Advisory Committee on Energy and Natural Resources has discussed increasing the use of renewable energy to make up $25-30 \%$ of Japan's total power supply by the year 2030, in which $20 \%$ is wind energy. The Japanese government estimates that at least 50 trillion yen ( $\$ 405$ billion) will be required to install sufficient renewable energy infrastructure by 2030 if it decides to completely phase out nuclear power [11]. This will require significant investment from both the public and private sectors.

\section{Wind Policies and Projects in Vietnam}

Vietnam is lacking a legal framework for the implementation of wind energy projects [12]. There are not enough support mechanisms in place to gives investors the required security for their investment. This explains why the Ministry of Industry and Trade in cooperation with the German Technical Cooperation (Deutsche Gesellschaft für Internationale Zusammenarbeit GmbH or GIZ) has carried out a project entitled "Establishment of legal framework and technical assistance for grid-connected wind power development in Vietnam". One of the main goals of the project is to design a price-based support mechanism for wind energy. The main incentive of the Vietnamese Government is a $100 \%$ tax exemption for imported wind power technology and equipment. In addition, investors in wind energy projects have a land rent exemption over a certain period of time. A guideline for potential foreign investors in wind power in Vietnam has been published by EC ASEAN Energy Facility. The permitting procedures for energy projects are relatively complex and possibly act as a disincentive for potential investors.

The Vietnam National Assembly promulgated Electricity Law in 2004 by Law No. 28/2004/QH11, dated on December 3rd 2004 [13]. This law is approved by the 
Vietnam National Assembly session XI. This law has clearly given rules for general development of electricity in Vietnam.

In 2007, the Vietnamese Government promulgated a Decision, No. 130/2007/QD-TTg on several financial mechanisms and policies applied to investment projects on clean development mechanisms [14]. The Decision was dated August $2^{\text {nd }} 2007$. The Decision provides for the investment project according to clean development mechanisms and several financial mechanisms, policies applied to investment project according to Clean Development Mechanism.

In 2007, the Vietnamese Government also promulgated another Decision, No. 1855/2007/QD-TTg on Vietnam's national energy development strategy up to 2020, with a vision through 2050. This Decision was approved by the Prime Minister on December $31^{\text {st }}$ 2007. According to this Decision the government said that the forms of new and renewable energy has not been fully evaluated, so there should be plans and appropriate investment for additional investigation data, future planning, and zoning of renewable energies for the next investment planning. The government encourages people to use sources of new and renewable energy from mountain regions, rural areas, borders and islands.

In 2008, MoIT promulgated a Decision, No. 18/2008-BCT, dated July $18^{\text {th }} 2008$ [15]. The Decision was approved by the MoIT on promulgation of the regulation on avoided cost tariff and standardized power purchase agreement for small renewable energy power plants. The Decision giving regulations on electricity purchase contracts apply to small power plants using renewable energy. According to this Decision, the EVN had to buy all electricity from the small power plants using renewable energy with a good price which is controlled by the Vietnamese Government. The Decision is invalid now. The Decision was replaced by the Circular No. 32/2014/TT-BCT, dated October $9^{\text {th }} 2014$ [16].

In 2011, the Vietnamese government promulgated a Decision on the mechanism supporting the development of wind power projects in Vietnam, Decision No.37/2011/QDTTg, dated June $29^{\text {th }} 2011$ [17]. The Decision said that the EVN will buy all electricity from the wind power plants in 20 years with a good purchase price enforced by the government. The price was set at $\$ 0.078 / \mathrm{kW}$ before VAT and the government also supports an addition of $\$ 0.01 / \mathrm{kW}$ from the Vietnamese Foundation of Environmental Protection.

To develop the electricity sector in conjunction with the national socio-economic development strategies, ensure adequate supply of electricity for the national economy and social life, in 2011, the Vietnamese Government also promulgated another Decision to approve the national master plan for power development of the 2011 - 2020 period with the vision to through 2030, No.1208-QD-TTg, dated July $21^{\text {st }} 2011$ [18]. With this Decision, the Government gave priority to the development of renewable energy sources for electricity production, increasing the percentage of electricity produced from renewable energy sources from 3.5\% of total electricity production in 2010 up to $4.5 \%$ in 2020 and $6.0 \%$ in 2030. It is expecting to bring the total wind power capacity from the current negligible levels to around 1,000 MW by 2020, about 6,200 MW by 2030; increase the proportion of electricity production from wind power from $0.7 \%$ in 2020 to $2.4 \%$ in 2030 . This Decision also said that the government has given priority to use the sources of new and renewable energy to supply electricity to mountains, border and island areas. To do these developments, the government wants to attract capital from overseas, including official incentive development aid, official non-incentive development aid, and commercial overseas loans. The Decision also creates the encouragement of cooperation between large enterprises in energy production and consumption among countries to 
implement clean development mechanism under the forms of development of new and renewable energy.

In 2012, the government promulgated a Decision on the National Green Growth Development Strategy, Decision No. 1393/2012/QD-TTg, dated September $25^{\text {th }} 2012$ [19]. The government confirmed that green growth is an important part of sustainable development to ensure fast, efficient and sustainable growth while making a significant contribution to the implementation of the national climate change strategy. The green growth is by the people and for the people, contributing to employment, poverty reduction and improving the material and spiritual life of all people. The government wants to change the energy structure in the way that the share of energy which originates from fossil fuel is gradually decreased, and encourage the exploitation and use of new and renewable and low greenhouse gas emission energy sources.

In 2012, MoIT also promulgated a Circular on guiding the financial mechanism to support electricity price for grid connected wind power projects, Circular No. 96/2012/TT-BTC, dated June $8^{\text {th }} 2012$ [20]. This Circular is guiding for the Decision No.37/2011/QD-TTg mentioned above. The Circular reaffirmed that the Vietnamese Foundation of Environmental Protection has to support wind power plants on electric purchasing price and make a report to the government every year.

In 2013, MoIT promulgated a Circular on the Content, Process and Procedures for Preparation, Validation and Approval of Wind Power Development Planning, Circular No.06/2013/TT-BCT, dated March 8 2013 [21]. According to this Circular, the Government has decentralized national wind power development to provinces.

Currently, in the end of 2015, Vietnamese government promulgated a Decision on Vietnam's renewable energy development strategy up to 2030 with an outlook to 2050, Decision No. 2068/2015/QD-TTg, dated November $25^{\text {th }} 2015$ [22]. This Decision said that from now to 2030, the government is going to prioritize developing wind power onshore. Nearshore and offshore wind power development will be focused later on after 2030. The percentage of power produced from wind is going to rise from 180 million $\mathrm{kWh}$ in 2015 to 2.5 billion $\mathrm{kWh}$ in 2020, 16 billion $\mathrm{kW}$ in 2030, and 53 billion $\mathrm{kW}$ in 2050. This development will make the wind power rate in the total electricity of the nation from currently being negligible to reach to $1.0 \%$ in 2020, about $2.7 \%$ in 2030 and about $5.0 \%$ in 2050 .

Following these policies, some wind power plants have been built. The first wind turbine with hundreds $\mathrm{kW}$ was built in Bach Long Vy island. It is an $858 \mathrm{~kW}$ wind turbine by Made Tecnologias Renovables, S.A., built in 2003 [23].

In 2008, the Tuy Phong wind farm project consisting of 20 wind turbines of 1.5 MW each, supplied by Fuhrlaender started to be built. It spans an area of around 500ha onshore Binh Thuan province. The construction of the first phase with 5 wind turbines was finished in September 2009. In the second phase, the wind farm was extended by another 15 wind turbines. It was connected to the grid in 2012. To transmit the power to the national grid about $1.5 \mathrm{~km}$ of $110 \mathrm{kV}$ transmission lines have been built. In a planned third phase, the wind farm will be extended to $120 \mathrm{MW}$.

In 2010, Cong Ly Construction-Trade-Tourism Co. Ltd. started to build a $99 \mathrm{MW}$ Bac Lieu wind power plant in the southern province of Bac Lieu. The first wind turbine was connected to the national grid in May 2013. The project was fully completed on January $17^{\text {th }}$ 2016. This company also started the construction of phase 1 of $100 \mathrm{MW}$ Khai Long-Ca Mau tourism zone wind power plant in the southernmost province of Ca Mau. 
The 100 MW power plant, to be built on a total of 2,165 hectares of land and sea surface area, is scheduled for completion in 2018. It will be connected to the national grid and also sell its power to EVN.

In 2012, Phu Quy island hybrid wind power plant was built. The total capacity power is $9 \mathrm{MW}$, including $6 \mathrm{MW}$ wind power (3 turbines x $2 \mathrm{MW}$ ) and $3 \mathrm{MW}$ diesel generator.

Currently, some other wind power plants have been built or are scheduled to be built soon in Vietnam. Thanh Tung group has cooperated with AVANTIS Energy Group to build Vietnam's largest wind farm in Mau Son, in the Chinese border. The wind farm will have the total capacity of $200 \mathrm{MW}$. The Group will operate hotels there and is also active in the field of renewable energies, in the real estate sector and in various other fields of business. Binh Thuan wind power JSC also has built a wind power plant in Phu Lac in three phases. The total capacity of the plant is around $170 \mathrm{MW}$, in which phase 1 has built $24 \mathrm{MW}$ (16 turbines x $1.5 \mathrm{MW}$ ). Thuong Tin power JSC has a plan to build a Phuoc Dan wind farm. The project was licensed in December 2008. However, as of now, the construction has yet to kick off, despite the province's prodding.

\section{Discussion}

With good policies for wind energy development, Japan's wind resources were developing at a very modest, but steady rate of approximately $250 \mathrm{MW} /$ year from 2001 to 2011. Thereafter, wind power development dropped to approximately $50 \mathrm{MW} / \mathrm{year}$, even as wind power costs continued their steady decline. However, following the East Japan earthquake and the nuclear incident at Fukushima, all reactors in Japan were required to pass newly revised safety standards to confirm their continued ability to operate safely in the event of a natural disaster and remain closed until Japanese authorities reviewed and accepted the results.

The Fukushima accident marked a turning point for Japan in energy development, calling for a revised Strategic Energy Plan as the Japanese Government confirmed its intentions of reducing its nuclear energy dependency as much as possible. Offshore turbines, which have garnered a lot of support in Japan after the Fukushima disaster, enjoy the benefit of more stable wind than onshore models, and are more efficient because they are not hampered by the constraints posed by land and transportation. In 2013, Japan has a total of 49.7 MW of offshore wind installed capacity using 28 turbines at

8 locations. The majority of existing installations are fixed-bottom turbines (45.7 MW of total installed capacity) located very close to shore $(<2.5 \mathrm{~km})$ in water depths up to $25 \mathrm{~m}$. Early demonstration floating turbines (4 MW of total installed capacity) are located further from shore $(15-25 \mathrm{~km})$ in water depths more than $100 \mathrm{~m}$.

Contrary to Japan, Vietnam is poor in encouraging policies for wind energy development that there are not a lot of wind power plants built in the country. This problem prevents the development of wind power in the country. For example, Binh Thuan is the province with highest potential of wind energy in Vietnam. However, with more than ten significant wind power plants planned to be built in the past, only two of them have been built, many others were delayed or cancelled.

\section{Conclusions}

Vietnam's wind energy potential is considerably higher compared to its neighboring countries Thailand, Laos or Cambodia. Vietnam is one of the ASEAN countries with wind 
potential conducive for generating electricity. However, compared to Japan, the wind potential in Vietnam is not so high.

With well-suited policies for wind energy development, Japan currently has 326 wind energy plants, in which 68 plants are operated by public sectors (Municipalities, NEDO, METI), and the remaining 258 plants by private sectors. While onshore wind turbines are dominated by international manufacturers, $86 \%$ of offshore wind turbines are manufactured by Japanese companies, with Hitachi and Fuji pre-eminent. Increasingly, local companies are also starting to develop larger models, with Mitsubishi developing a 7 MW turbine. This upsizing is important for the economics of wind farms as they move from demonstration to full scale deployment. In the opposite site, Vietnam does not have feasible wind development policies. Therefore, only some wind power plants have been built in Vietnam.

The Japanese government has adequate and clear policies on wind power development. As a result, wind power developing companies find ease in their investment in wind power plants in the country.

Vietnam is a developing country so laws and policies in the country are not stable. In a period of ten years, from 2007 to 2016, there have been so many Decisions and Circulars promulgated by the Government. These frequent changes have prevented the development of wind power projects in Vietnam. Many wind power plants were scheduled to be built in Vietnam in the past. However, since the law and policies are not so clear and stable, many of these plants have been delayed or cancelled.

For the sustainable development of wind power and to encourage both local and international investors, Vietnam should learn from the policies that Japan has adopted, such as the Feed-in-tariff policy.

\section{References}

[1] True Wind Solutions, Wind Energy Resource Atlas of Southeast Asia, Prepared for the World Bank Asia Alternative Energy Program, New York, United States, 2001.

[2] R. Komiyama, and Y. Fujii, "Assessment of renewable energy in nation-wide power grid in Japan by optimal power generation mix model” Paper presented at The $68^{\text {th }}$ Semi-Annual ETSAP Meeting, CMA, Mines ParisTech, Sophia Antipolis, France, 2015.

[3] Electricity of Vietnam, Wind Resource Assessment for Power Generation, Hanoi, Vietnam, 2007.

[4] AWS Truepower, Wind Resource Atlas of Vietnam, Prepared for AWS Truepower, LLC, Socialist Republic of Vietnam, New York, United States, 2011.

[5] Ministry of the Environment, Government of Japan, Brief Overview of Japanese Offshore Wind Projects and Initiatives, Tokyo, Japan, 2011.

[6] T. Tsanova, “Orix takes 33.3\% in 100-MW offshore wind project in Ibaraki," SeeNews Renewable, May 28, 2015 [Online], Available: http://renewables.seenews.com/news/ orix-takes-33-3-in-100-mw-offshore-wind-project-in-ibaraki-478184 [Accessed:

October, 2017].

[7] Bloomberg, "Fukushima Wind Project to Add Largest Turbine Ever Used at Sea," 2015 [Online], Available: http://www.bloomberg.com/news/articles/2015-06-17/fukushimawind-project-to-add-largest-turbine-ever-used-at-sea [Accessed: October, 2017]. 
[8] 4C Offshore, "Latest events on floating offshore wind turbine demonstration project Sasebo-1:10 scale prototype,” 2013 [Online], Available: http://www.4coffshore.com/ windfarms/floating-offshore-wind-turbine-emonstration-project-sasebo---1-10-scaleprototype-japan-jp18.html [Accessed: October, 2017].

[9] Ministry of Environment, Trade and Industry, Government of Japan, Feed-in-Tariff Scheme in Japan, Tokyo, Japan, 2013.

[10] Deutsche Bank Group, The German Feed-in Tariff: Recent Policy Changes, New York, United States, 2012.

[11] British Embassy Tokyo, Appraisal of the Offshore Wind Industry in Japan, Carbon Trust, Tokyo, Japan, 2014.

[12] Vietnam Ministry of Industry and Trade, Government of Vietnam, German Corporation for International Cooperation GmbH, GIZ/MoIT Information on Wind Energy in Vietnam, Hanoi, Vietnam, 2011.

[13] The Vietnam National Assembly session XI, Electricity Law, Law No. 28/2004/QH11, Hanoi, Vietnam, 2004.

[14] Government of Vietnam, Decision No. 130/2007/QD-TTg, Hanoi, Vietnam, 2007: The Prime Minister.

[15] The Ministry of Industry and Trade, Government of Vietnam, Decision No. 18/2008BCT, Hanoi, Vietnam, 2008.

[16] The Ministry of Industry and Trade, Government of Vietnam, Circular No. 32/2014/ TT-BCT, Hanoi, Vietnam, 2014.

[17] Government of Vietnam, Decision No.37/2011/QD-TTg, Hanoi, Vietnam, 2011: The Prime Minister.

[18] Government of Vietnam, Decision No.1208-QD-TTg, Hanoi, Vietnam 2011: The Prime Minister.

[19] Government of Vietnam, Decision No. 1393/2012/QD-TTg, Hanoi, Vietnam, 2012: The Prime Minister.

[20] The Ministry of Industry and Trade, Government of Vietnam, Circular No. 96/2012/ TT-BTC, Hanoi, Vietnam, 2012.

[21] The Ministry of Industry and Trade, Government of Vietnam, Circular No.06/2013/ TT-BCT, Hanoi, Vietnam, 2013.

[22] Government of Vietnam, Decision No. 2068/2015/QD-TTg, Hanoi, Vietnam, 2015: The Prime Minister.

[23] A.T. Phan, D. Nguyen, T.T. H. Pham, "Research and Development of Wind Power in Vietnam," VSOE 2018, Lecture Notes in Civil Engineering, Vol. 18, pp.270-275, 2018. doi: https://doi.org/10.1007/978-981-13-2306-5_37 